\title{
DIE REGSTEORETIESE GRONDSLAG VAN DIE INTEGRASIEREËL IN DIE SUID-AFRIKAANSE KONTRAKTEREG ${ }^{1}$
}

\author{
Thino Bekker \\ BJuris LLB LLM LLD \\ Senior Lektor, Departement Prosesreg \\ Universiteit van Pretoria
}

\section{SUMMARY}

This article focuses on an extensive critical analysis of the legal-theoretical basis of the parol evidence rule in the South African law of contract. Certain conclusions will be made from such an analysis in terms of which it will be argued that the parol evidence rule qualifies as a legal rule and that it can therefore be validly abolished or modified by the legislature.

\section{INLEIDING}

Thayer het meer as 'n eeu gelede reeds van die ekstrinsieke-getuienis-reël gesê:

"Few things are darker than this, or fuller of subtle difficulties".

Wigmore het op 'n soortgelyke trant verklaar dat die reël:

"is attended with a confusion and an obscurity which makes it the most discouraging subject in the whole field of Evidence".

Burger het die toepassing van die reël treffend soos volg verwoord:

"In truth, its application is much like venturing into an intricate labyrinth without a guide".

Die begrip "ekstrinsieke getuienis-reël" ("parol evidence rule") is op sigself 'n wanbeskrywing wat dit volgens Zeffertt, Paizes en Skeen in gemeen het met die Heilige Romeinse Ryk:

"the distinction of being misleading in all three of its component parts". 5

\footnotetext{
Hierdie artikel is gebaseer op Bekker Die Ekstrinsieke Getuienis-reël in die Suid-Afrikaanse Kontraktereg (2009) ongepublisserde LLD-tesis Universiteit van Suid-Afrika.

2 Thayer Preliminary Treatise on Evidence at the Common Law (1898) 390.

3 Wigmore A Treatise on the Anglo-American System of Evidence in Trials at Common Law Vol 9 3ed (1940) par 2400.

4 Burger "The Parol Evidence Rule in Contract" 1996 Die Landdros 141.
} 
Eerstens, beskou menige persone die reël as 'n reël van die substantiewe reg en nie van die bewysreg nie. Getuienismateriaal word deur die reël uitgesluit, nie omdat dit inherent onbetroubaar of onvanpas is nie, maar omdat die substantiewe reg dit regtens oneffektief verklaar en daarom bewys daarvan verbied. ${ }^{6}$

Tweedens, insinueer die Engelse beskrywing "parol" dat dit slegs mondelinge getuienis is wat uitgesluit word. Dit is egter ook misleidend aangesien die reël beide geskrewe en mondelinge getuienis kan uitsluit. ${ }^{7}$ Zeffertt, Paizes en Skeen wys byvoorbeeld daarop dat ook die volgende getuienis (anders as mondelinge getuienis) deur die werking van die reël uitgesluit word:

"It includes the direct testimony of the parties, their extra-curial statements, and their physical acts which are tendered to supplement and contradict a complete transaction, and it excludes documents and correspondence other than those that actually constitute the transaction or act being considered. And it is not confined only to written contracts. Thus, for instance, it has been applied to judicial documents and even to unilateral, non formal acts such as the written declarations of deceased persons that had been made in the course of a duty."

Ten slotte is daar nie net slegs een onverdeelde ekstrinsieke-getuienisreël nie, maar ten minste twee wyer konsepte wat binne die reël se trefwydte val. Die een konsep handel met die mate waarin 'n skriftelike kontrak as die enigste uiteensetting van sy bedinge ("sole memorial of its terms") beskou kan word, waarna daar in hierdie artikel as die "integrasiereël" verwys word. Die ander konsep het te doen met uitleg, of die mate waarin die betekenis van die bedinge van 'n skriftelike kontrak geraak kan word deur ekstrinsieke getuienis, waarna daar in die algemeen verwys kan word as die "interpretasiereël". ${ }^{9}$

Beide reëls het in Engeland ontstaan en is vandaar na die verskillende common law-lande en ook na Suid-Afrika versprei. ${ }^{10}$ Die bestaan en toepassing van beide hierdie reëls is egter uiters omstrede, nie net wat die verskillende buitelandse regstelsels aanbetref nie, maar ook die SuidAfrikaanse reg. In hierdie opsig heers daar tans 'n Babelse verwarring in die Suid-Afrikaanse reg indien die regspraak op hierdie gebied nagegaan word.

5 Zeffertt, Paizes en Skeen The South African Law of Evidence (voorheen Hoffmann \& Zeffertt) (2003) 321. Die "Heilige Romeinse Ryk" het natuurlik nie bestaan uit Romeine nie, maar Germane, was geensins "heilig" nie (aangesien baie "onheilighede" aan die orde van die dag was in hierdie "Ryk") en het verder ook glad nie gekwalifiseer as 'n "Ryk" nie. Vir hewige kritiek op die gebruik van die beskrywing "parol evidence rule" in die Amerikaanse reg sien Daniel "K.I.S.S. the Parol Evidence Rule Goodbye: Simplifying the Concept of Protecting the Parties' Written Agreement" 2007 Syracuse Law Review 227 235-236.

6 Zeffertt en Paizes Parol Evidence with Particular Reference to Contract Centre for Banking Law (1986) 1.

7 lbid.

8 Zeffertt, Paizes en Skeen 321-322. In S v Ngesi 19862 SA 244 (E) is die reël byvoorbeeld toegepas ten aansien van 'n padvervoerpermit.

9 Zeffertt en Paizes 1.

10 Meiskin v Miklejohn (1870) 2 QSCR 59 (Australië); Cash v Chaffer (1897) 15 NZLR 416 (Nieu-Seeland); Moran v Mitta Bibee (1876) ILR 2 Calc 58; Daimoddee Paik v Kaim Taridar (1879) ILR 5 Calc 300 (Indië); Prowse v Wingfield (1854) 4 Nfld 51; en Mathews v Holmes (1855) CR 2 AC 230; McAlpine v How (1862) 9 Gr 72 (Kanada). 
Die posisie word vererger deur die feit dat daar 'n aansienlike begripsverwarring bestaan ten aansien van die komponente waaruit die ekstrinsieke-getuienis-reël bestaan. Die gebreke in die Suid-Afrikaanse reg ten aansien van die reël is lankal reeds deur vooraanstaande skrywers op hierdie gebied, soos Zeffertt en Paizes, uitgewys. ${ }^{11}$

Hierdie omstredenheid het ook gekulmineer in 'n ondersoek deur die Suid-Afrikaanse Regskommissie. Die aanbeveling van hierdie Kommissie kom daarop neer dat die reël effektief afgeskaf en vervang behoort te word met 'n kriptiese statutêre bepaling. ${ }^{12}$

Daar is talle voorstanders vir die afskaffing van die ekstrinsieke-getuienisreël, nie net in Suid-Afrika nie, maar ook in verskeie buitelandse jurisdiksies. Hierdie voorstanders gaan hoofsaaklik van die standpunt uit dat die reël geensins daarin slaag om regsekerheid, eenvoud en voorspelbaarheid tot gevolg te hê nie, dat dit gekompliseerd en verwarrend is, en dat dit onbillik teen "onskuldige" kontrakspartye kan inwerk.

Aan die ander kant is daar ook ' $n$ aantal (alhoewel in die minderheid) voorstanders vir die behoud van die reël. Die hoofargumente van hierdie voorstanders is dat die reël regsekerheid, eenvoud en voorspelbaarheid tot gevolg het en beskerming verleen aan die onskendbaarheid ("sanctity") van die skriftelike kontrak.

Indien daar aanvaar word dat die integrasiereël wel afgeskaf of gemodifiseer behoort te word sal daar natuurlik eers aangetoon moet kan word dat hierdie "reël" wel neerkom op 'n regsreël en derhalwe vatbaar is vir afskaffing of modifikasie. Indien die grondslag van die integrasiereël neerkom op 'n beding van die skriftelike kontrak of 'n ooreenkoms tussen die partye om te integreer, sal moontlike wetgewing moet neerkom op ' $n$ verbodsbepaling van so 'n beding of ooreenkoms en sal die wetgewer nie by magte wees om die integrasiereël bloot af te skaf nie. Ten einde vas te stel of die integrasiereël wel afgeskaf kan word deur die wetgewer of, indien nie, die werking daarvan op 'n ander wyse gereguleer sal moet word, is dit derhalwe nodig om 'n omvattende kritiese analise van die regsteoretiese grondslag van die integrasiereël in die Suid-Afrikaanse kontrakterereg te maak, wat dan ook die fokus van hierdie artikel is. Daar sal dan ook ondersoek ingestel word of die integrasiereël neerkom op 'n uitdruklike of stilswyende beding deur die partye om te integreer, 'n beding wat van regsweë ingelees word (naturale), 'n ooreenkoms (uitdruklik of stilswyend) tussen die partye om te integreer of 'n blote regsreël. Op grond van sodanige analise sal daar dan ook sekere gevolgtrekkings gemaak word oor die wyse waarop die integrasiereël gereguleer behoort te word in die SuidAfrikaanse kontraktereg.

1 Zeffertt en Paizes 8ev.

12 Suid-Afrikaanse Regskommissie Report on Unreasonable Stipulations in Contracts and the Rectification of Contracts Projek 47 (April 1998). 


\section{REGSTEORETIESE GRONDSLAG VAN DIE INTE- GRASIEREËL}

Van der Merwe et al (met verwysing na regspraak) ${ }^{13}$ voer aan dat die rede vir die bestaan van die integrasiereël daarin geleë is dat, waar die partye self hulle ooreenkoms in 'n skriftelike dokument wat 'n volledige en finale "kristallisasie" van hulle wilsooreenstemming is, geïntegreer het, ekstrinsieke getuienis ten aansien van die onderhandelinge en inhoud van hulle ooreenkoms irrelevant en misleidend is. ${ }^{14}$

Lubbe and Murray, met verwysing na regspraak, ${ }^{15}$ beskou 'n geïntegreerde skriftelike kontrak as 'n abstraksie van alles wat vooraf tussen die partye plaasgevind het. Lubbe and Murray is van mening dat die gevolg wat voortvloei uit hierdie abstraksie 'n aanname ("assumption") is dat addisionele getuienis ten aansien van die partye se ooreenkoms oortollig en irrelevant is aangesien dit nie die hof enige iets meer kan vertel wat nie alreeds in die skriftelike kontrak vervat is nie. ${ }^{16}$ Volgens Joubert beteken die integrasiereël nie dat ekstrinsieke getuienis nie aangebied kan word in litigasie met betrekking tot kontraktuele dispute nie, maar dat dit slegs aangebied kan word vir sover dit relevant is. ${ }^{17}$

Kerr, met verwysing na regspraak, ${ }^{18}$ verklaar op sy beurt dat daar nie verwag word dat die ware impak ("real import") van 'n skriftelike kontrak op 'n ander plek gevind kan word as die bedinge daarin vervat nie. ${ }^{19}$

Volgens Christie dien die integrasiereël die belangrike doel om te verseker dat waar die partye besluit het dat hulle ooreenkoms op skrif gestel moet word, hierdie besluit gerespekteer sal word en die skriftelike kontrak derhalwe aanvaar sal word as die enigste getuienis van die bedinge van die ooreenkoms. ${ }^{20}$

Die vraag bly egter steeds wat die grondslag is van die integrasiereël. Myns insiens is daar vier moontlikhede, naamlik:

- 'n Uitdruklike of stilswyende beding deur die partye om te integreer;

- 'n beding wat van regsweë ingelees word (naturale);

- 'n ooreenkoms (uitdruklik of stilswyend) tussen die partye om te integreer;

- 'n blote regsreël.

13 National Board (Pretoria) (Pty) Ltd v Estate Swanepoel 19753 SA 16 (A); Johnston v Leal 19803 SA 927 (A); en Traub v Barclays National Bank Ltd 1983 3 SA 619 (A).

14 Van der Merwe, Van Huyssteen, Reinecke and Lubbe Contract General Principles 3ed (2007) 174.

15 African Films Trust Ltd v Popper 1915 TPD 201 204; en Du Plessis v Nel 19521 SA 513 (A) 534.

16 Lubbe and Murray Farlam and Hathaway Contract Cases, Materials and Commentary 3ed (1988) 216.

17 Joubert General Principles of the Law of Contract (1987) 58.

18 Premier, Free State v Firechem Free State (Pty) Ltd [2000] 3 All SA 247 (A).

19 Kerr The Principles of the Law of Contract 6ed (2002) 349.

20 Christie The Law of Contract in South Africa 5ed (2006) 176. 
Dit is baie belangrik om hierdie onderskeid te maak aangesien dit ' $n$ wesenlike invloed het op die wyse waarop die integrasiereël moontlik afgeskaf kan word. Indien die grondslag van die integrasiereël neerkom op 'n beding van die skriftelike kontrak of 'n ooreenkoms tussen die partye om te integreer sal moontlike wetgewing moet neerkom op 'n verbodsbepaling van so ' $n$ beding of ooreenkoms. ${ }^{21}$ Indien die grondslag van die integrasiereël egter bloot op 'n regsreël berus, kan die integrasiereël wel afgeskaf word. 'n Uitdruklike beding en uitdruklike ooreenkoms is nie problematies nie en daar sal in die bespreking wat volg gekonsentreer word op die ander moontlikhede ten aansien van die grondslag van die integrasiereël.

\section{Stilswyende beding}

'n Stilswyende beding is ' $n$ beding wat voortvloei (of na bewering voortvloei) uit die gemeenskaplike bedoeling van die partye wat nie deur hulle uitgedruk is nie. ${ }^{22}$ So ' $n$ beding word afgelei uit die uitdruklike bedinge en omringende omstandighede van 'n kontrak, asook die gedrag van die partye na kontraksluiting. ${ }^{23}$ Die bestaan van 'n stilswyende beding kan nie afgelei word waar dit onversoenbaar sou wees met die uitdruklike bedinge van die kontrak nie. ${ }^{24}$

Om die bestaan van 'n stilswyende beding vas te stel het ons howe die sogenaamde "innocent bystander"-toets vanuit die Engelse reg aangeneem. ${ }^{25}$ Hierdie toets is soos volg in die Engelse saak Reigate $v$ Union Manufacturing Co (Ramsbottom) geformuleer: ${ }^{26}$

"You must only imply a term if it is necessary in the business sense to give efficacy to the contract; if it is such a term that you can be confident that, if at the time the contract was being negotiated, someone had said to the parties: 'What will happen in such a case?' they would have both replied 'Of course, so-and-so. We did not trouble to say that; it is too clear'."

21 Sien ook die bespreking infra.

22 Van der Merwe et al 279; Christie 167; en Kerr 338. In die saak van Alfred McAlpine \& Son (Pty) Ltd v Transvaal Provincial Administration 1974 3 SA 506 (A) 531-532 het Corbett WAR die volgende omskrywing aan 'n stilswyende beding gegee: "an unexpressed provision of the contract which derives from the common intention of the parties, as inferred by the Court from the express terms of the contract and the surrounding circumstances. In supplying such an implied term the Court, in truth, declares the whole contract entered into between the parties". Sien Kerr 339-341 vir 'n kritiese bespreking ten aansien van die terminologie wat gebruik word om stilswyende bedinge te beskryf.

23 Alfred McAlpine \& Son (Pty) Ltd v Transvaal Provincial Administration supra 531-532; en Botha $v$ Coopers \& Leibrand 20025 SA 347 (HHA) 360.

24 First National Bank of SA Ltd v Rugby Union 19973 SA 851 (W) 864; Kelvinator Group Services (Pty) Ltd v McCulloch 19994 SA 840 (W) 844; en Transnet Ltd v Rubenstein 2006 1 SA 591 (HHA) 598-599.

25 Van der Merwe et al 280; en Christie 169 en 171 wys daarop dat die eerste deel van hierdie toets in die Engelse reg bekend staan as die "Moorcock-doctrine" met verwysing na die Engelse saak van The Moorcock (1889) 14 PD 64 en die tweede deel as die "officious bystander"-toets. Lubbe en Murray verwys ook na die "officious bystander"-toets. Kerr 356 voer aan dat die toets ook beskryf word as die "hypothetical bystander"-, die "inquisitive bystander"- en die "imaginative bystander"-toets.

2619181 KB 592605

27483. 
Die howe het dit egter op verskeie geleenthede benadruk dat hulle nie maklik 'n stilswyende beding in 'n kontrak sal inlees nie. ${ }^{28}$ In City of Cape Town (CMC Administration) $v$ Bourbon-Leftley $y^{29}$ het die hof aangevoer dat die rede hiervoor is dat die howe nie kontrakte vir partye kan maak nie en ook nie hulle ooreenkomste kan aanvul bloot omdat dit redelik of gerieflik is om dit te doen nie.

Christie, met verwysing na regspraak, ${ }^{30}$ wys heeltemal tereg daarop dat, waar 'n aangeleentheid ondubbelsinnig gereël word deur 'n uitdruklike beding, geen stilswyende beding in die kontrak ingelees kan word om dieselfde aangeleentheid te reël nie. ${ }^{31}$ Indien die uitdruklike beding egter dubbelsinnig is, word die deur oopgelaat vir die bevinding van die bestaan van 'n stilswyende beding.

Van der Merwe et al wys daarop dat dit met die eerste oogopslag lyk of ons howe hierdie toets verstaan dat dit beteken dat die stilswyende beding werklik deur die kontrakspartye bedoel moes gewees het. ${ }^{32}$ Hulle voer egter oortuigend aan dat hierdie standpunt misleidend is aangesien die partye se versuim om die beding in hulle kontrak in te sluit omrede die feit is dat die partye nie daaraan gedink het tydens hulle onderhandelinge nie en nie die feit dat hulle daaraan gedink het, maar verkies het om dit nie in te sluit nie omdat dit te voor die hand liggend was. Indien die partye dan nie aan die beding gedink het tydens hulle onderhandelinge nie, kan daar later beswaarlik aangevoer word dat hulle bedoel het dat die beding deel van hulle ooreenkoms moes vorm. Alles inaggenome is Van der Merwe et al van mening dat die howe die bedoeling van die partye vooropstel by die bepaling van die bestaan van 'n stilswyende beding wat dan verklaar waarom die stilswyende beding nie teenstrydig mag wees met die uitgedrukte bedoeling van die partye nie. ${ }^{33}$

Die howe verwys ook in die meeste gevalle na die veronderstelde bedoeling van die partye. Soos Van der Merwe et al egter aanvoer, beteken dit bloot dat daar gevalle is wat die gevolgtrekking regverdig dat die beweerde beding binne die trefwydte van die partye se werklike bedoeling val, al het hulle die betrokke beding nie in gedagte gehad nie. ${ }^{34}$ Die howe maak ook gebruik van objektiewe faktore om die veronderstelde bedoeling van die partye vas te stel, naamlik die sake-effektiwiteit ("business-efficacy")

28 Techni-Pak Sales (Pty) Ltd v Hall 19683 SA 231 (W) 236; Alfred McAlpine \& Son (Pty) Ltd v Transvaal Provincial Administration supra 532; Wilkins v Voges 19943 SA 130 (A) 136-137 en 143; Botha $v$ Coopers \& Leibrand supra; Birkenruth Estates (Pty) Ltd v Unitrans Motors (Pty) Ltd 20053 SA 54 (W) 64; Consol Ltd h/a Consol Glass v Twee Jonge Gezellen (Pty) Ltd 20056 SA 1 (HHA); en City of Cape Town (CMC Administration) v Bourbon-Leftley 2006 3 SA 488 (HHA) 494-495.

29 Supra 494.

30 Mullin (Pty) Ltd v Benade Ltd 19521 SA 211 (A) 215; en Cape Town Municipality v Silber 19712 SA 537 (K) 543.

31 Christie 168

32 Van der Merwe et al 280.

33 Van der Merwe et al 281.

34 Ibid. 
van die kontrak ${ }^{35}$ en dit waarop redelike kontrakspartye ooreen sou kom in die omstandighede van die betrokke geval. ${ }^{36}$ In hierdie opsig is die "innocent bystander"-toets dan ook geobjektiveer. ${ }^{37}$

Christie wys daarop dat die "innocent bystander"-toets ook in die volgende twee gevalle objektief toegepas moet word: ${ }^{38}$

- Eerstens, is dit nie nodig om te bewys dat die partye ooit hulle aandag op die betrokke beding gevestig het nie ${ }^{39}$ en

- tweedens, moet daar aangeneem word dat die partye eerlik gehandel het. $^{40}$

Nog ' $n$ beginsel wat algemeen toepassing vind by stilswyende bedinge is dat die stilswyende beding wat in die kontrak ingelees wil word, duidelik en presies geformuleer moet kan word. ${ }^{4}$

Die howe gebruik egter nie altyd in alle gevalle die "innocent bystander"toets nie. In Minister van Landbou-tegniese Dienste $v$ Scholtz, ${ }^{42}$ byvoorbeeld, het die hof 'n beding dat 'n bul vrugbaar was, ingelees in die skriftelike kontrak al was dit duidelik dat die waarborg teen verborge gebreke wel sou kon geld. Die remedies beskikbaar vir verborge gebreke wat gebaseer is op die aedilisiese aksies het egter verjaar en die hof het derhalwe bevind dat daar ' $n$ stilswyende waarborgsbeding in die kontrak ingelees moet word. Die waarborg teen verborge gebreke sou egter kon geld aangesien die bul vir teeldoeleindes aangekoop was en die verkoper daarvan bewus was. Die stilswyende beding wat in die kontrak ingelees is, was ook nie nodig om sake-effektiwiteit aan die transaksie te verleen nie. Van Blerk WHR, wat die meerderheidsuitspraak van die hof uiteengesit het, het bloot bevind dat daar duidelik uit die getuienis en die omringende omstandighede afgelei kan word dat die partye die ooreenkoms aangegaan het met die verstandhouding dat die verkoper onderneem het om 'n bul te lewer wat vir teeldoeleindes geskik is en dat dit derhalwe 'n stilswyende beding van die ooreenkoms was. ${ }^{43}$

Vorster voer oortuigend aan dat die "innocent bystander"-toets nie in hierdie geval van toepassing was nie aangesien dit 'n bewese feit was dat die partye 'n onuitgedrukte gemeenskaplike bedoeling ten aansien van 'n

35 Wilkins $v$ Voges supra; en Standard Bank of SA Ltd v Durban Security Glazing (Pty) Ltd 20001 SA 146 (D) 164.

Wilkins $v$ Voges supra 141; en Joubert 67-68.

Van der Merwe et al 282.

Christie 171-172.

Wilkins $v$ Voges supra 136

Administrator (Tvl) v Industrial and Commercial Timber and Supply Co Ltd 1932 AD 2533.

Rapp and Maister v Aronovsky 1943 WLD 68 75; en Desai v Greyridge Investments (Pty) Ltd 19741 SA 509 (A) 522-523.

4219713 SA 188 (A). Sien ook die bespeking van hierdie saak deur Lubbe and Murray 425429; en Vorster Implied Terms in the Law of Contract in England and South Africa (1987) ongepubliseerde LLD-tesis 118-121. Vgl ook Van den Berg v Tenner 19752 SA 268 (A); Alfred McAlpine \& Son (Pty) Ltd v Transvaal Provincial Administration supra; Cardoso v Tuckers Land and Development Corporation 19813 SA 54 (W); Petersen v Incorporated 43201. General Insurances 19823 SA 1 (K); en Falch v Wessels 19834 SA 172 (T). 
bepaalde aspek gehad het. ${ }^{44}$ Volgens Vorster het die hof in die onderhawige geval bevind dat daar uitdruklike wilsooreenstemming tussen die partye bestaan het al was dit nie uitdruklik so in hulle ooreenkoms uitgedruk nie. ${ }^{45}$

\section{Bedinge wat van regsweë ingelees word (naturalia)}

'n Verdere moontlikheid is dat die integrasiereël kan neerkom op 'n naturale ${ }^{46}$ van die skriftelike kontrak. Naturalia is onuitgedrukte bedinge wat as 'n reël by wyse van regsweë op elke kontrak van 'n bepaalde klas van toepassing gemaak word. ${ }^{47}$ In die saak van A Becker \& Co (Pty) Ltd v Becker $^{48}$ is daar verklaar dat die naturalia van die onderskeie spesifieke kontrakte wat aan die Suid-Afrikaanse kontraktereg bekend is op Romeinsregtelike beginsels van redelikheid en billikheid gebaseer is. In die saak van Alfred McAlpine \& Son (Pty) Ltd $v$ Transvaal Provincial Administration ${ }^{49}$ het die hof verklaar dat naturalia 'n objektiewe bepaler van die kontraktuele inhoud is gegrond op oorwegings van die openbare beleid en die beginsel van goeie trou. ${ }^{50}$

\section{Ooreenkoms}

Om die bestaan van 'n stilswyende ooreenkoms vas te stel het die howe twee verskillende toetse ontwerp. Die eerste toets staan bekend as die sogenaamde "geen-ander-redelike-uitleg"-toets en is soos volg in Standard Bank of South Africa Ltd $v$ Ocean Commodities $I n c^{51}$ geformuleer:

"In order to establish a tacit contract it is necessary to show, by a preponderance of probabilities, unequivocal conduct which is capable of no other reasonable interpretation than that the parties intended to, and did in fact, contract on the terms alleged. It must be proved that there was in fact consensus ad idem".

44 Vorster 120.

45 Vorster 120 kritiseer ook die minderheidsuitspraak van De Villiers WAR waar hy verwys het na die "Moorcock"-leerstuk om sy uitspraak te ondersteun dat daar nie 'n stilswyende beding in die kontrak ingelees kan word dat daar gewaarborg is dat die bul inderdaad vrugbaar was nie.

46 Salmond en Williams gebruik die begrip van "implied term" in Engels om hierdie tipe beding te beskryf om dit te onderskei van wat hulle 'n "tacit term"-(stilswyende) beding noem.

47 Van der Merwe et al 283; Christie 159; Joubert 65; Lubbe and Murray 417; en Kerr 338. Vir ' $n$ bespreking van die onderskeid tussen stilswyende bedinge en naturalia (of geïmpliseerde bedinge), sien Minister van Landbou-tegniese Dienste v Scholtz supra 197.

$48 \quad 1981$ 3 SA 406 (A).

49 Supra.

50 Vgl ook Van der Merwe et al 283; Lubbe en Murray 417; Van Nieuwkerk v McCrae 20075 SA 21 (W); en South African Forestry Co Ltd v York Timbers Ltd 20053 SA 323 (HHA), waar Brand AR verklaar het dat: "Indeed, our courts have recognized explicitly that their powers of complementing or restricting the obligations of parties to a contract by implying terms should be exercised in accordance with the requirements of justice, reasonableness, fairness and good faith."

5119831 SA 276 (A).

52292. 
In Joel Melamed and Hurwitz $v$ Cleveland Estates (Pty) $L t d^{53}$ het Corbett AR egter die korrektheid van bogemelde formulering bevraagteken en het hy die sogenaamde "oorwig van waarskynlikhede"-toets uiteengesit:

"In this connection it is stated that a court may hold that a tacit contract has been established where, by a process of inference, it concludes that the most plausible probable conclusion from all the relevant proved facts and circumstances is that a contract came into existence".

Christie voer aan dat hierdie twee toetse op sigwaarde onversoenbaar is. ${ }^{55}$ Christie is van mening dat dit nie nodig is om enigeen van die twee toetse in sy totaliteit te verwerp nie aangesien dit moontlik is om 'n sintese te bereik wat die beste eienskappe van beide toetse inkorporeer. Christie voer dan ook aan dat dit nodig is om eers die volgende drie proposisies te ondersoek alvorens sodanige sintese bereik kan word:

- In die eerste plek behoort die reëls uiteengesit in $R v B / o m^{56}$ ten aansien van "reasoning by inference", soos aangepas vir siviele gedinge, ${ }^{57}$ sover dit moontlik is toegepas te word. Volgens Christie is die "oorwig van waarskynlikhede"-toets in ooreenstemming met hierdie reëls, maar nie die "geen-ander-redelike-uitleg"-toets nie. ${ }^{58}$

- Tweedens behoort elke aanbod en elke aanname "unequivocal", met ander woorde, positief en ondubbelsinnig, te wees. Daar behoort nie toegelaat te word dat dubbelsinnige aanbiedinge en aannames deur die net van "reasoning by inference" val nie. ${ }^{59}$

- Derdens behoort die toets vir die vassteliing van 'n stilswyende ooreenkoms nie wesenlik te verskil van die toets vir die vasstelling van 'n stilswyende beding nie. Volgens Christie is twee van die toetse wat deur die Hoogste Hof van Appèl aangeneem is ${ }^{60}$ om 'n stilswyende beding vas te stel in ooreenstemming met die "geen-ander-redelike-uitleg"-toets, maar nie die "oorwig-van-waarskynlikhede"-toets nie. ${ }^{61}$

Op grond hiervan stel Christie oortuigend voor dat die ideale sintese verkry kan word deur 'n ondersoek deur die howe wat uit die volgende drie fases behoort te bestaan:

- Tydens die eerste fase moet 'n hof op 'n oorwig van waarskynlikhede bevind watter feite vasgestel is.

- Die tweede en finale fase bestaan daaruit dat die hof op 'n oorwig van waarskynlikhede moet besluit watter gevolgtrekking wat konsekwent is met die vasgestelde feite waarskynlik korrek is.

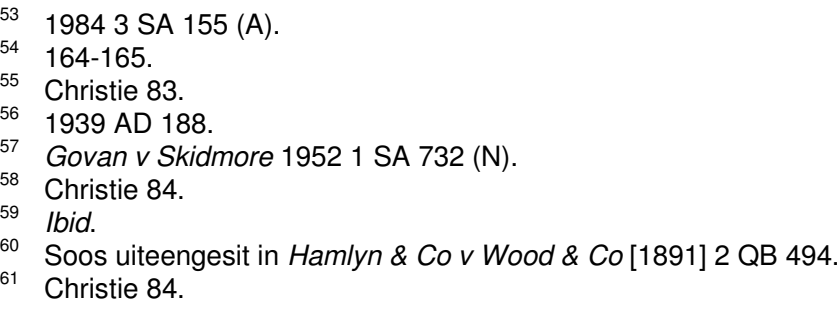


- Om vas te stel of 'n stilswyende ooreenkoms bewys is, moet 'n derde fase tussen bogemelde twee fases geplaas word, naamlik om te besluit hoe die bewese feite, wat uit die gedrag van elke party en die omringende omstandighede bestaan, deur die ander party uitgelê moes gewees het. ${ }^{62}$

\section{Regsreël}

In die Suid-Afrikaanse reg kan daar 'n onderskeid tussen drie verskillende tipes vermoedens getref word, naamlik:

- Die onweerlegbare regsvermoede (preasumptio iuris et de iure) wat deur middel van regsweë op 'n hof afgedwing word en wat nie deur getuienis weerlê kan word nie. ${ }^{63}$

- Die weerlegbare regsvermoede (praesumptio iuris tantum) bepaal ook dat 'n hof van regsweë verplig is om die betrokke aanname te maak as die grondslag daarvoor gelê is, maar die werking daarvan word opgehef sodra weerleggende getuienis ten aansien daarvan aangebied word. ${ }^{64}$

- Die feitelike vermoede wat nie ' $n$ regsreël is nie, maar wat bloot in werking tree waar die hof ' $n$ afleiding vanuit die bewese feite maak. ${ }^{65}$

In Silver Garbus \& Co (Pty) Ltd v Teichert ${ }^{66}$ het Henochsberg R verklaar dat die onweerlegbare regsvermoede ' $n$ onding of ' $n$ blote fiksie is. Ook in Roxa $v$ Mtshay $^{67}$ het Corbett AR verklaar dat die onweerlegbare regsvermoede ten aansien van 'n kind onder die ouderdom van sewe jaar 'n regsfiksie is. In Scagell $v$ Attorney General of the Western Cape ${ }^{68}$ het $O$ 'Regan $\mathrm{R}$ verklaar dat 'n onweerlegbare regsvermoede nie ' $\mathrm{n}$ reël van die bewysreg nie, maar ' $n$ reël van die substantiewe reg is. Die feit dat die integrasiereël dan moontlik kwalifiseer as 'n onweerlegbare regsvermoede maak nie die argument tot niet dat die integrasiereël eintlik deel van die materiële reg uitmaak nie.

Olivier voer oortuigend aan dat 'n judisiële regsfiksie die aard van 'n regsreël aanneem:

"Numerous rules of modern law are based on rules which developed centuries ago and were then based on fictions. The rules have been received and developed by modern law, but the underlying fictions have been forgotten".

Olivier wys daarop dat judisiële regsfiksies 'n uiters belangrike en voordelige rol gespeel het in die ontwikkeling van die reg. Deur hulle regskeppende vermoëns weg te steek agter die fasade van fiksies was

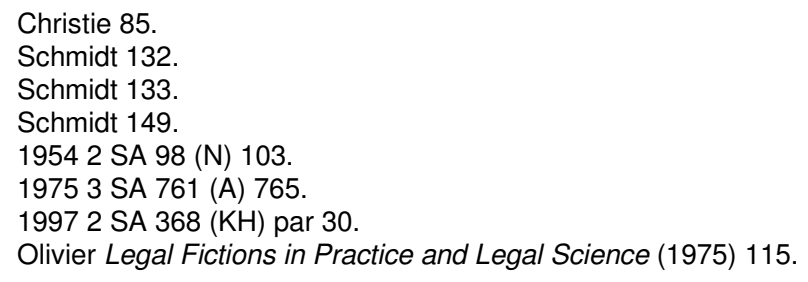


regters in staat gestel om regsreëls aan te pas en uit te brei om billike bevindings te maak. $^{70}$

\section{KRITIESE BESPREKING VAN DIE GRONDSLAG VAN DIE INTEGRASIEREËL}

Indien bogemelde beginsels op die integrasiereël toegepas word, kan die volgende gevolgtrekkings gemaak word: In die eerste plek is dit duidelik dat die partye uitdruklik kan ooreenkom om te integreer, in welke geval hulle bedoeling uitdruklik plaasvind. Dit gebeur dikwels dat partye hulle toevlug neem tot ' $n$ beding wat ontwerp is om die status van 'n dokument as ' $n$ integrasie onbetwisbaar te maak. Daar is al verskeie benamings aan sodanige beding of klousule gegee, byvoorbeeld integrasiebeding, ${ }^{71}$ samesmeltingsbeding, ${ }^{72}$ enigste-ooreenkomsbeding ${ }^{73}$ en volle-ooreenkomsbeding.

In Standard Bank of SA Ltd $v$ Cohen (1) $)^{75}$ is daar verklaar dat klousules soos hierdie bedinge van die ooreenkoms is en nie net blote feitelike erkennings nie. Ekstrinsieke getuienis is in so 'n geval selfs ontoelaatbaar om aan te toon dat daar slegs ' $n$ gedeeltelike integrasie plaasgevind het. Gevolglik is dit dus duidelik dat die partye op 'n uitdruklike wyse die bedoeling kan openbaar om te integreer.

Wat is egter die posisie waar daar nie 'n integrasiebeding in die skriftelike kontrak vervat is nie? Uit regspraak blyk dit duidelik dat die howe nog nooit die "innocent bystander"-toets aangewend het waar die integrasiereël van toepassing was nie. Dit blyk myns insiens verder duidelik dat die insluiting van die integrasiereël in 'n ooreenkoms by wyse van 'n stilswyende beding nie noodwendig noodsaaklik is om sake-effektiwiteit aan die onderliggende transaksie te verleen nie. Dit is verder myns insiens duidelik dat die partye by kontraksluiting nie noodwendig soos volg sou verklaar nie: "Dit is ons bedoeling om ons ooreenkoms ten volle te integreer en geen getuienis van enige ander ooreenkoms of verklaring sal toelaatbaar wees nie; dit is so duidelik dat ons dit nie nodig gevind het om dit uitdruklik so te stel in die skriftelike kontrak nie., ${ }^{76}$

Wat is egter die posisie waar die howe nie gebruik maak van die "innocent bystander"-toets om die bestaan van 'n stilswyende beding vas te stel soos in die Scholtz-saak ${ }^{77}$ nie? In so 'n geval is daar klaarblyklik nie eers sprake van die fiksie van die partye se bedoeling nie. In hierdie opsig moet daar egter met Vorster saamgestem word, waar hy indirek verklaar dat hierdie

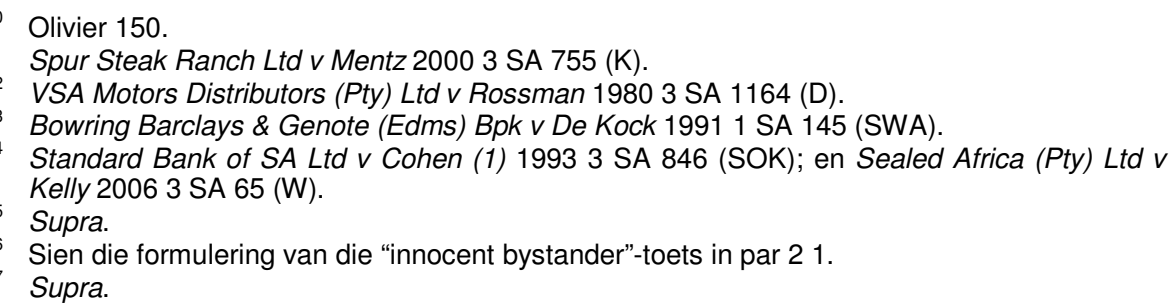


saak nie kwalifiseer as 'n alternatiewe toets vir die vasstelling van 'n stilswyende beding nie, aangesien dit gegaan het oor 'n onuitgedrukte gemeenskaplike bedoeling ${ }^{78}$ Indien hierdie argument korrek is, beteken dit dat hierdie saak eerder kwalifiseer as 'n geval van 'n uitdruklike beding of ooreenkoms tussen die partye.

Die volgende vraag is of die integrasiereël dalk kwalifiseer as 'n naturale. Sekere naturalia geld gewoonlik slegs ten aansien van 'n bepaalde klas van kontrak en daar kan derhalwe nie aangevoer word dat die integrasiereël kwalifiseer as 'n naturale van alle skriftelike kontrakte nie. Van der Merwe et al wys daarop dat die oorwegings wat aanleiding gee tot die ontwikkeling van bepaalde naturalia vir bepaalde klasse van kontrakte, daartoe mag lei dat sodanige gevolge deel uitmaak van alle kontrakte in die algemeen. Van der Merwe et al voer egter aan dat dit te betwyfel is of daar enige waarde daarin lê om sodanige algemene gevolge as naturalia te behandel eerder as gewone regsreëls. ${ }^{79}$ Myns insiens berus die integrasiereël ook nie op enige hedendaagse beleidsoorwegings wat bepaal dat dit 'n naturale van enige skriftelike kontrak moet wees dat die partye hulle volle ooreenkoms in die skriftelike kontrak geïntegreer het nie. Ter ondersteuning hiervan is daar ook geen aanduiding in die regspraak dat die howe die integrasiereël as 'n naturale beskou nie.

Uit voorgaande blyk dit dus myns insiens dat die grondslag van die integrasiereël nie op 'n stilswyende beding of naturale kan berus nie.

Dit blyk verder ook dat die howe nog nooit enige van die stilswyendeooreenkoms-toetse aangewend het waar die integrasiereël in 'n betrokke geval toepassing gevind het nie. Selfs indien die betrokke toetse ten aansien van die integrasiereël aangewend word, is dit myns insiens moeilik om te sien hoe die integrasiereël as 'n stilswyende ooreenkoms tussen die partye sal kan kwalifiseer.

Indien die "geen-ander-redelike-uitleg"-toets aangewend word, moet daar aangetoon word dat die feit dat die partye hulle ooreenkoms op skrif gestel het kenmerkend is van ondubbelsinnige ("unequivocal") gedrag wat op 'n oorwig van waarskynlikhede daarop dui dat daar geen ander redelike uitleg daaraan geheg kan word as dat die partye bedoel het om hulle ooreenkoms te integreer nie en dat hulle dit inderdaad geïntegreer het. Myns insiens sal die blote handeling van opskrifstelling nie hierdie gevolgtrekking kan regverdig nie.

Indien die "oorwig-van-waarskynlikhede"-toets aangewend word, moet daar aangetoon word dat die waarskynlikste gevolgtrekking vanuit al die relevante bewese feite en omstandighede moet wees dat 'n kontrak (om die ooreenkoms te integreer) in die lewe geroep is. Daar kan natuurlik geredeneer word dat die integrasiereël slegs van toepassing is waar daar ' $n$ volledige integrasie van die partye se ooreenkoms plaasgevind het en nie net 'n gedeeltelike integrasie nie. Waar die relevante bewese feite en omstandighede gevolglik aantoon dat die waarskynlikste gevolgtrekking is

78 Vorster 120. Sien ook die bespreking in par 21.

79 Van der Merwe et al 283. 
dat die partye stilswyend ooreengekom het om hulle ooreenkoms te integreer sal dit 'n geval van volledige integrasie wees en sal die integrasiereël van toepassing wees.

Omgekeerd, indien die relevante bewese feite en omstandighede aantoon dat die waarskynlikste gevolgtrekking is dat die partye nie stilswyend ooreengekom het om hulle ooreenkoms te integreer nie sal dit 'n geval van gedeeltelike integrasie wees en sal die integrasiereël nie van toepassing wees nie. Ingevolge hierdie argument sal die integrasiereël dan wel kan kwalifiseer as 'n stilswyende ooreenkoms. Myns insiens is hierdie argument egter problematies weens die vereiste van die "relevante bewese feite en omstandighede". Dit is moeilik om ander "relevante bewese feite en omstandighede" as opskrifstelling te voorsien wat aantoon dat die partye wel ooreengekom het om hulle volle ooreenkoms in die skriftelike kontrak te integreer. Myns insiens kan selfs die handeling van opskrifstelling nie noodwendig die afleiding regverdig dat die partye bedoel het om te integreer nie. As gevolg van hierdie problematiek sal die integrasiereël dan myns insiens ook nie kan kwalifiseer as 'n stilswyende ooreenkoms ingevolge hierdie toets nie.

Indien Christie se "sintese"-toets aangewend word, sal daar eerstens aangetoon moet word dat die hof op 'n oorwig van waarskynlikhede sekere feite vasgestel het wat aanduidend was van 'n ooreenkoms tussen die partye om te integreer. In die tweede plek sal daar aangetoon moet word dat die waarskynlikste gevolgtrekking vanuit die vasgestelde feite is dat die partye hulle ooreenkoms geïntegreer het. Laastens sal daar ook verder aangetoon moet word dat die gedrag van elke party en die omringende omstandighede op so 'n wyse deur die ander party uitgelê moes gewees het om te verstaan dat daar wel ' $n$ volledige integrasie plaasgevind het. Die kritiek teen die aanwending van hierdie toets om aan te toon dat die integrasiereël neerkom op 'n stilswyende ooreenkoms is weer eens dieselfde as die kritiek teen die "oorwig-van-waarskynlikhede"-toets. Dit is naamlik baie moeilik om te voorsien hoe die omringende omstandighede en die gedrag van een van die partye, anders as opskrifstelling, enigsins die indruk teenoor die ander party sal kan wek dat daar wel 'n volledige integrasie van hulle ooreenkoms in die skriftelike kontrak plaasgevind het. Myns insiens sal selfs die handeling van opskrifstelling nie noodwendig die afleiding kan regverdig dat daar ' $n$ indruk van integrasie teenoor 'n party gewek is nie.

In die lig van bogemelde bespreking kwalifiseer die integrasiereël myns insiens dan ook nie as 'n stilswyende ooreenkoms tussen die partye om hulle ooreenkoms te integreer nie.

Ten slotte kan daar geredeneer word dat die integrasiereël miskien gedeeltelik gebaseer is op wilsooreenstemming (uitdruklike ooreenkoms of beding) en gedeeltelik op 'n regsfiksie of regsreël. Myns insiens is hierdie argument slegs geldig waar die partye 'n uitdruklike integrasiebeding in hulle skriftelike kontrak vervat het. Aangesien die integrasiereël egter ook werking geniet in die afwesigheid van so 'n beding kan daar myns insiens nie 
aangevoer word dat die grondslag van die integrasiereël enigsins berus op 'n uitdruklike beding of ooreenkoms nie.

Indien die integrasiereël nie gekategoriseer kan word as ' $\mathrm{n}$ uitdruklike ooreenkoms of beding, of ' $n$ stilswyende beding of ooreenkoms nie, bly daar slegs een opsie oor, naamlik dat dit kwalifiseer as 'n blote regsreël. Myns insiens kwalifiseer die integrasiereël dan ook as 'n onweerlegbare, of teenstellende, weerlegbare regsvermoede, of 'n blote regsfiksie.

Daar kan in die eerste plek 'n argument uitgemaak word dat die integrasiereël kwalifiseer as ' $n$ weerlegbare regsvermoede aangesien daar weerlegbaar vermoed word dat die partye hulle volle ooreenkoms in die skriftelike kontrak geïntegreer het. Hierdie vermoede kan dan weerlê word deur middel van die aanbieding van ekstrinsieke getuienis om aan te toon dat daar slegs 'n gedeeltelike integrasie van die partye se ooreenkoms plaasgevind het. In gevalle waar 'n party daartoe in staat is om te bewys dat daar slegs ' $n$ gedeeltelike integrasie van die ooreenkoms plaasgevind het en, waar die kollaterale beding of ooreenkoms nie die skriftelike hoofkontrak weerspreek nie, sal die integrasiereël wel kan kwalifiseer as 'n weerlegbare regsvermoede.

Weens die problematiek daaraan verbonde om te bewys dat daar slegs ' $n$ gedeeltelike integrasie plaasgevind het, tesame met die feit dat, om 'n gedeeltelike integrasie te bewys, die ander ooreenkoms waarop gesteun word nie teenstrydig mag wees met die skriftelike hoofkontrak nie, is dit egter verkieslik om die integrasiereël eerder in die meeste gevalle vir alle praktiese doeleindes te beskou as 'n onweerlegbare regsvermoede. Wanneer daar dan 'n opskrifstellingshandeling deur die partye van hulle ooreenkoms plaasgevind het, word daar onweerlegbaar vermoed dat daar 'n volledige integrasie van die partye se ooreenkoms plaasgevind het. Daar kan natuurlik geargumenteer word dat die aanwesigheid van een van die talle "uitsonderingsgevalle" die vermoede van integrasie sal weerlê, maar soos reeds aangetoon, kwalifiseer die oorgrote meerderheid van uitsonderingsgevalle nie as ware uitsonderings op die integrasiereël nie, maar eerder as gevalle waar die reël glad nie van toepassing is nie.

Selfs al kwalifiseer die integrasiereël nie as 'n regsvermoede nie, kan daar nog steeds aangevoer word dat die reël bloot kwalifiseer as 'n regsfiksie. Dit is so aangesien die handeling van opskrifstelling op ' $n$ fiktiewe wyse gesien word as 'n bedoeling deur die partye om hulle ooreenkoms in die skriftelike kontrak te integreer.

\section{GEVOLGTREKKING}

Watter argument ook al korrek is, die resultaat bly dieselfde. Aangesien 'n onweerlegbare regsvermoede neerkom op 'n regsfiksie, maak dit ook nie saak of daar direk aangevoer word dat die integrasiereël op ' $n$ fiksie berus of op 'n onweerlegbare regsvermoede nie. Die feit bly bestaan dat, indien die integrasiereël op 'n direkte of indirekte wyse kwalifiseer as 'n regsfiksie, die reël ook kwalifiseer as 'n regsreël wat by wyse van wetgewing vatbaar is vir afskaffing of modikasie. 